\title{
Introduction: Dimensions of Social Innovation
}

\author{
Alex Nicholls, Julie Simon and Madeleine Gabriel
}

\section{Introduction}

Social innovation is not new, but it appears to be entering a new phase a phase in which it is increasingly seen as offering solutions not just to localised problems but to more systemic and structural issues. Nevertheless, the growing set of examples and attendant discourses and logics of social innovation have yet to coalesce around a single, common definition, a set of standards or performance measures or an agreed policy agenda. Partly, this is the consequence of the 'liability of newness' experienced by all new fields of action: namely, they lack the legitimacy needed to support significant investment or research. It may also be because the range and variety of action that constitutes social innovation today defies simple categorisation. Indeed, this fluidity and diversity may be seen as one of the field's great strengths in terms of addressing complex social problems and challenges. So, as yet, there is no established paradigm of social innovation (see also Nicholls, 2010a).

However, there are strong signs that interest is growing in this institutional space where innovative thinking and models can address both problems of social welfare efficiency or distribution and imbalances and inequalities in social structures and relations. Moreover, interest in this field appears to cut across governments, civil society and even mainstream businesses and investors. It has also become a topic for scholarly enquiry and research (see e.g., Nicholls and Murdock, 2012). This book aims to explore the multiple dimensions of social innovation - both theoretically and empirically - in order to advance research and contribute to shaping the formation of its boundaries and to advancing a wider recognition of the opportunities and challenges of this new phase. 
In particular, this volume aims to challenge some of the emerging normative assumptions about the 'promise of social innovation', namely a general acceptance that it is an unproblematic and consistently positive phenomenon without drawbacks or unintended consequences. Thus, this collection explores the implications of social innovation in cross-sector collaborations and hybrid forms, across several contexts and in multiple country settings to highlight a range of issues across social innovation models. The research presented here deliberately ranges across different socio-structural levels and units of analysis - from micro to macro - in order to offer multiple insights into the various contexts in which social innovation can operate effectively. Much of the work here also has strong policy implications: by codifying and analysing practice, its objective is to inform future policy making in social innovation across countries. This book also aims to contribute to the critical field-building project of social innovation that is already underway across a range of researchers and institutions by augmenting the existing body of knowledge on this subject with work on new trends and case examples. In the process, the hope is that the work published here will also support the building of a community of researchers looking at social innovation by adding its own, modest legitimacy to working on this subject. The contents and structure of this volume are considered in more detail below.

\section{Definitions}

At its simplest, social innovation can be seen as 'new ideas that address unmet social needs - and that work' (Mulgan et al., 2007, p. 2). In practice, social innovations can take the form of specific ideas, actions, frames, models, systems, processes, services, rules and regulations as well as new organisational forms. However, more specifically, there are two interlinked conceptualisations of social innovation, focused on either new social processes or new social outputs and outcomes. The first emphasises changes in social relations and often has a focus on rebalancing power disparities of economic inequalities in society (see Moulaert et al., 2014a). For example, Mumford (2002, p. 253) suggested that:

Social innovation refers to the generation and implementation of new ideas about how people should organize interpersonal activities, or social interactions, to meet one or more common goals. 
Westley and Antadze (2010, p. 2) subsequently expanded upon this by noting that:

Social innovation is a complex process of introducing new products, processes or programs that profoundly change the basic routines, resource and authority flows, or beliefs of the social system in which the innovation occurs. Such successful social innovations have durability and broad impact.

Second, social innovation can be seen as the answer to social market failures in the provision of vital public goods. This is reflected in the OECD's definition of social innovation, which also includes a reference to the process dimensions of social innovation $(2011$, p. 1$)$ :

Social innovation is distinct from economic innovation because it is not about introducing new types of production or exploiting new markets in itself but is about satisfying new needs not provided by the market (even if markets intervene later) or creating new, more satisfactory ways of insertion in terms of giving people a place and a role in production.

In addition to these two meta-definitions, three levels of social innovation can be identified (see Table I.1). First, there is incremental innovation in goods and services to address social need more effectively or efficiently. This is the objective of many successful charities and notfor-profits, as well as some so-called 'Bottom of the Pyramid' (Prahalad, 2006) commercial firms. From this perspective, social innovation may simply be a good business opportunity. Second, there is institutional innovation that aims to harness or retool existing social and economic structures to generate new social value and outcomes. Examples such as Fair Trade (Nicholls and Opal, 2005) or mobile banking typically exploit or modify existing market structures to deliver new or additional social value. Finally, disruptive social innovation aims at systems change. This is typically the realm of social movements and self-consciously 'political' actors, groups and networks aiming to change power relations, alter social hierarchies and reframe issues to the benefit of otherwise disenfranchised groups. Disruptive social innovation can be characterised by structured mass participation in political parties or formal membership schemes of social movements, on the one hand, or loose coalitions of individuals and interests united by an evanescent issue or technology such as social media, on the other. Policy entrepreneurs from within 
4 Alex Nicholls, Julie Simon and Madeleine Gabriel

Table I.1 Levels of social innovation

\begin{tabular}{llll}
\hline Level & Objective & Focus & Examples \\
\hline Incremental & $\begin{array}{l}\text { To address identified } \\
\text { market failures more } \\
\text { effectively }\end{array}$ & Products & $\begin{array}{l}\text { Kickstart (low-cost } \\
\text { irrigation foot pump) }\end{array}$ \\
Institutional & $\begin{array}{l}\text { To reconfigure existing } \\
\text { market structures and } \\
\text { patterns }\end{array}$ & Markets & M-PESA (mobile banking) \\
Disruptive & $\begin{array}{l}\text { To change cognitive } \\
\text { frames of reference to } \\
\text { alter social systems } \\
\text { and structures }\end{array}$ & Politics & Tostan (human rights) \\
& & & \\
\hline
\end{tabular}

Source: Nicholls and Murdock (2012).

Table I.2 Dimensions of social innovation

\begin{tabular}{lll}
\hline Dimension & Social process & Social outcome \\
\hline Individual & $\begin{array}{l}\text { Co-Production (Southwark } \\
\text { Circle) }\end{array}$ & $\begin{array}{l}\text { Lost-cost Healthcare } \\
\text { (Aravind Eye Hospital) }\end{array}$ \\
Organisation & Wiki-Production (Wikipedia) & $\begin{array}{l}\text { Work Integration Social } \\
\text { Enterprise (Greyston Bakery) }\end{array}$ \\
Network/ & Open Source Technology & $\begin{array}{l}\text { Non-Traditional Training and } \\
\text { Education (Barefoot College) }\end{array}$ \\
System & Microfinance (Grameen Bank) & Mobile Banking (MPESA) \\
\hline
\end{tabular}

Source: Nicholls and Murdock (2012).

state structures can also drive disruptive social innovation by focussing on reforming democracy and enlarging or deepening citizens' roles within it.

Social innovation can also be defined in terms of the level of its action or impact from the individual to the systems level (micro-, meso- or macrolevel). Such levels or dimensions can be mapped against the two main definitions of social innovation focused either on new social processes or on new social outcomes (see Table I.2). These differing levels of impact point to the complexity of performance measurement on social innovation and emphasise the need for clarity about the unit of impact of a social innovation.

Social innovation can also be considered in the context of the more institutionalised fields of social entrepreneurship (Dees, 1998; Nicholls, 2006) and social enterprise (Alter, 2006; Nyssens, 2006). In this setting, social innovation can be seen as the biggest field of 
action encompassing any new idea or model that addresses a social (or environmental) need. Social entrepreneurship can, then, be seen as a subset of social innovation - the organisational enactment of social innovation ideas and models.

Finally, drawing upon theory from design thinking, Murray et al. (2010) set out the key stages of the development of a social innovation as a nonlinear process. This model is characterised by a series of key inflection points where the development of an innovation moves first from prompts and proposals to prototyping (an important part of the design process), then to sustainability and, finally, to scale.

It should also be acknowledged that social innovation is not, in and of itself, a socially positive thing. Social innovation may have a 'dark side'. This could be evidenced in several ways:

- Socially divisive or destructive objectives and intentions (e.g., secret societies or extreme political parties)

- Deviant or unintended consequences that achieve negative social effects (e.g., by excluding some groups from the focus of social goods, services or change)

- Operational failure, mission drift or strategic co-option by an external party (e.g., Tracey and Jarvis, 2006)

It is well understood within innovation studies that innovations will create value for some and destroy it for others. This underlies Schumpeter's (1942) notion of 'creative destruction'. In the context of social innovation, however, the idea that social innovations might create winners and losers is rarely, if ever, articulated. Phills et al. (2008) appeared to recognise the potential for a dark side of social innovation in a definition that emphasises improvement rather than change as a central feature:

A novel solution to a social problem that is more effective, efficient, sustainable, or just than existing solutions and for which the value created accrues primarily to society as a whole rather than private individuals. (p. 36)

Moreover, this conceptualisation also highlights a potential bifurcation of value creation and value appropriation within social innovation that renders the interests of the individual (social) innovator secondary to wider social value creation (see Nicholls, 2010b, for a similar argument in the context of social investment). 
Clearly, social innovation is a complex and multi-faceted institutional space that is still subject to competing discourses and definitions. Moreover, as is illustrated in this collection, social innovation can have a 'dark side' that challenges normative assumptions that (social) innovation is always positive (i.e., improvement rather than just change). It is important, therefore, to be aware that social innovation from one stakeholder perspective may look and feel very different from another - social benefit is always contingent. As such, in terms of this collection, social innovation can be seen as:

Varying levels of deliberative novelty that bring about change and that aim to address suboptimal issues in the production, availability, and consumption of public goods defined as that which is broadly of societal benefit within a particular normative and culturally contingent context.

\section{Drivers}

As Moulaert et al. (2014b) noted:

Socially innovative actions, strategies, practices and processes arise whenever problems of poverty, exclusion, segregation and deprivation or opportunities for improving living conditions cannot find satisfactory solutions in the 'institutionalized field' of public or private action. (p. 2)

As such the growth of interest in social innovation as a field or set of tools and models reflects the failure - for at least some sections of society - of established systems (technology, markets, policy, governance, etc.) to deliver well-being and economic prosperity. This can be seen, fundamentally, as a distribution problem in terms of both mainstream innovation policy and democratic reform. Social innovation can be viewed, therefore, as partly a response to patterns of modernity that have marginalised certain populations and that see the individual citizen as essentially an economic/consuming actor, not as an active participant in collective decision-making. From this perspective social innovation is a sense-making process that, first, frames key issues and then proposes alternative worldviews (functioning much like the classic social movement: see Davis et al., 2005). This reading of the drivers of social innovation emphasises addressing sub-optimal configurations of social relations via new models of empowerment, engagement or political mobilisation. 
Of course, social innovation is also driven by simple welfare need. The increasing challenges of global warming, growing inequality (if not absolute poverty), demographics (notably a growing ageing population), migration, pandemics and terrorism have been compounded by the effective nationalisation by governments of the private sector financial crisis after 2008. Thus, the age of public sector austerity will likely stretch forward into the 2020s and beyond in many developed countries and this will continue to severely constrain welfare budgets. As a consequence, in both developed and developing country contexts, there will be a need for social innovation to address shortfalls and market failures in the provision of basic, universal, welfare services. ${ }^{1}$

One account of the increased focus on social innovation in recent years casts it as a response to an acceleration of global crises and so-called 'wicked problems' characterised by multiple and contradictory analyses and diagnoses (Rittel and Webber, 1973; Rayner, 2006; Mulgan et al., 2007; Murray et al., 2010), such as: climate change; social breakdown; rising life expectancy and associated health and social care costs; growing cultural diversity within and across countries; growing inequality; rising incidences of chronic long-term conditions and pandemics; behavioural problems associated with the 'challenge of affluence' (Offer, 2006); difficult transitions to adulthood; endemic reductions in individual happiness and indices of well-being. The rise of social innovation also demonstrates a collapse in trust in the status quo - as established models and social relations have increasingly failed to deliver well-being for many. In this context, intractable problems are seen as highlighting the failure of conventional solutions and established paradigms, entrenched in institutional settings across all three conventional sectors of society. This is evident through private sector market failures, public sector siloed thinking and a lack of scale in and fragmentation across civil society.

An important subset of these 'wicked problems' concerns welfare reform. After World War Two a new model of welfare provision emerged across many developed economies with the state delivering universal public services largely free at the point of access, funded by taxation and compulsory individual 'national' insurance. The centrepiece of many welfare states has been the development of powerful public healthcare systems. However, demographic and societal changes combined with the economic realities of rising welfare costs and worsening public finances have led to radical innovation in the provision of welfare goods and services in recent years (Leadbeater, 1997). In many cases 
this has involved a retreat from centralised state-led provision and an engagement with new 'partnership' models involving both the private and civil society sectors. A key objective has been increased economic efficiency, but there has also been a realisation that innovation and reform offer the opportunity to improve the effectiveness of services. ${ }^{2}$ For example, in both the United Kingdom and elsewhere there has been a clear move in public policy towards enabling greater 'choice' and control for the recipient of welfare services (Bartlett, 2009a and 2009b). Indeed, policy reform offers an important mechanism by which social innovation can be both incubated and enacted as a part of 'reinventing government' (Osborne and Gaebler, 1992). At the same time, there has been a crisis in the legitimacy of the democratic process in many developed countries with the consequence that social innovation is also being used as a set of processes to improve citizen engagement within the policy-making process.

In developing country contexts, public welfare has typically not developed in this way. Large welfare states are not present here. Nevertheless, social innovation models of mixed provision, co-creation and deep citizen participation in welfare - that are becoming entrenched in the developed nations - are also playing a role in emergent welfare states elsewhere (Nicholls, 2013). This is discussed further below.

An alternative view of this new phase of social innovation sees it as a necessary (but not always automatic) companion to rapid technological change and economic innovation (Hämäläinen and Heiskala, 2007). This conceptualisation presents social innovation as a process of reshaping social relations to maximise productivity and economic development, often framed by the (perhaps optimistic) assumption that the benefits of these changes will be shared equally across society. Such a reading also suggests that social entrepreneurship represents the reconciliation of an historical division between private and public sector mechanisms of productivity growth (Drayton, 2002). These approaches are at a systems level of analysis that relates most clearly to a disruptive vision of social innovation.

Common to all these drivers are a series of complex and multifaceted social contexts that drive innovation not only in processes and outcomes but also, increasingly, as boundary-blurring activity across the conventional sectors of society. As Murray et al. (2010) wrote:

Social innovation doesn't have fixed boundaries: it happens in all sectors, public, non-profit and private. Indeed, much of the most creative action is happening at the boundaries between sectors. (p. 3) 
Each of the three sectors of society - civil society, public and private - has its own internal logic of action and defining features. Taken together, these three ideal-type sectors can be conceptualised as a triad represented in stability as a triangle. Between each of the three ideal-type points lies a spectrum of hybrid institutions and organisations that represent sites for social innovation as a boundary-blurring activity (see Figure I.1). Thus, between the civil society sector and the private sector are social enterprises that combine business logics and models with social objectives and ownership structures (Alter, 2006). Some examples along this spectrum will be closer to the logic of business (i.e., businesses with a social purpose: see also Corporate Social Innovation, Moss Kanter, 1999) and some to that of civil society (i.e., not-for-profit organisations that have an earned income stream). In the spectrum between the private and public sector ideal types are hybrids such as public-private partnerships that aim to provide new models of welfare provision outside of, but in tandem with, the state (Bovaird, 2006). Finally, between the state and civil society ideal types lies the 'shadow state' in which civil society organisations function as a surrogate state, providing welfare where there is a public sector market failure. For example, in Bangladesh, BRAC and the network of Grameen organisations act as quasi-state providers of education, health, employment and

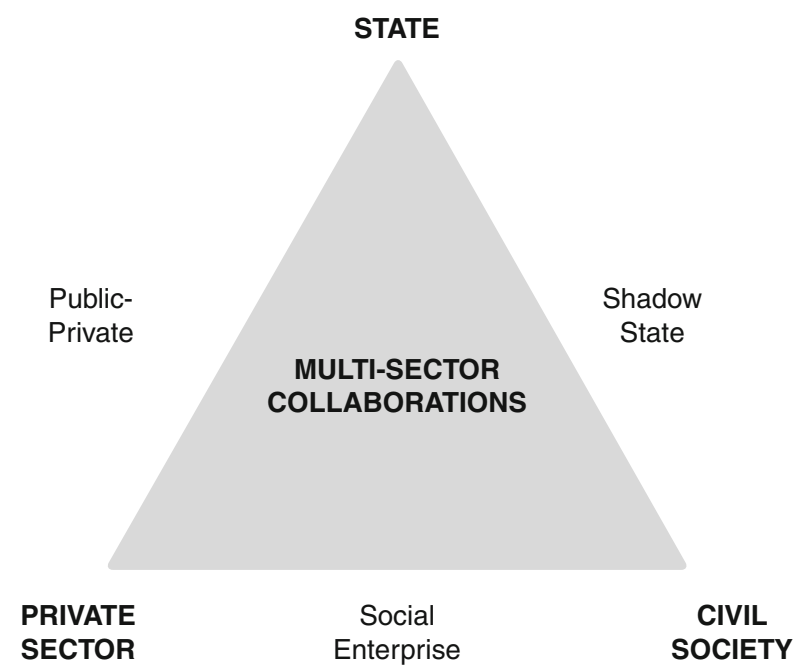

Figure I.1 The social innovation triad

Source: Nicholls and Murdock (2012). 
financial services across the country in and around institutional voids at the policy and market levels (Mair and Marti, 2009).

There are multiple, often sector-specific, drivers behind the growing relevance of social innovation across sectors. For the private commercial sector, there is an increasing recognition of social innovation as offering a model for new roles of business in society (e.g., the 'Shared Value' model, Porter and Kramer, 2012). For the state, social innovation links with traditions of welfare reform based on increased efficiency and effectiveness, also reflecting a move from a focus on New Public Management to Public Value and, more recently, New Public Governance. It may also challenge the governance status quo in societies by aiming to transform the power structures across social relations that allocate goods and services ineffectively or unequally. For civil society, social innovation may involve both internal processes of organisational change (such as new legal forms, collaborations and income strategies) and novelty in external outputs and outcomes (such as new products and services).

\section{Research themes}

To date, the research literature that focuses on social innovation specifically is limited, albeit growing. A review of this body of work reveals three clusters of research themes. Each is now considered in turn.

\section{Innovation in social relations}

The largest and most well-developed body of work on social innovation specifically focuses on innovation that addresses various dimensions of changes in social relations. This literature can be subdivided into five categories of scholarship:

1. Research Design Challenges: Early work on social innovation developed from within behavioural science with a particular interest in devising 'social change' approaches to tackle key, contemporary social problems, often at a community level (Fairweather, 1967). ${ }^{3}$

2. Changes in Social Structures: Hämäläinen and Heiskala (2007) argued that it is social innovation processes that ultimately determine the economic and social performance of nations, regions, and industrial sectors and organisations: 'Social innovations are changes in the cultural, normative or regulative structures of society which enhance its collective power resources and improve its economic and social performance' (2007, p. 59). 
3. Changes in Patterns of Work (or workplace innovation): Holt (1971) focused on social innovation within organisations, conceived of as new social patterns of employee interaction. This work was echoed in the activities of the Netherlands Centre for Social Innovation 30 years later (see Pot and Vaas, 2008).

4. Diffusion of Social Change: From within sociology, there are analyses of the micro-level structures of innovation and diffusion that affect society - for example, how medical innovations spread across groups of clinicians - that have been classed as social innovation. Henderson (1993) was interested in the relationship between social innovation and political change in terms of diffusion processes. He explored how citizen movements catalyse social innovation conceptualised as distinct from dominant cultural norms - from fluid positions outside of conventional societal structures.

5. Urban Studies: There is a significant cluster of work within urban studies exploring innovative responses to social exclusion as social innovation under the heading of Integrated Area Development. Much of this work centres on innovation within social relations in urban contexts, and as a body of work, it explores the potential of public, private and civil society models, interventions and interactions. In 2007, Moulaert et al. characterised social innovation as 'a polymorphic constellation of counter-hegemonic movements and initiatives' (p. 196) engaged in active processes of social struggle and change.

\section{Innovation to address social market failures}

This stream of work relates to the outcome-driven model of social innovation already discussed above and focuses on innovation as the means by which new products and services can be provided to underserved market segments. At the macro level, this includes the mechanisms by which new markets are created in weak institutional spaces or to address market failures. The latter is conceived of as encompassing failures not only in commercial markets but also in public sector 'markets', where the state fails to provide public goods, and civil society 'markets', where charities, not-for-profits and NGOs fail to provide effective goods and services to their beneficiaries (Nicholls, 2006). High-profile examples include developments focused on the Bottom of the Pyramid (Prahalad, 2006) or frugal innovation (Jugaad) models (Zeschky et al., 2011). However, while such failures typically provide innovation opportunities, they can also offer challenges in terms of reconciling potentially competing institutional logics (Battilana and Dorado, 2010). 


\section{Resilience theory}

A third strand of social innovation theory has emerged recently focusing on its relationship with the overall sustainability and, particularly, the resilience of the larger ecosystem within which it evolves. The overall resilience of a system may be examined through the lens of the adaptive cycle, which is graphically represented by an infinity loop encompassing four phases: release, reorganisation, exploitation and conservation. The exploitation and conservation phases in the 'front' loop represent periods of growth and resource accumulation, where change is routine and almost always adaptive, while the release and reorganisation phases in the 'back' loop can represent the introduction of novelty, either transformative (radical) or adaptive change, and renewal of the system. The back loop, therefore, represents a precarious moment from the point of view of whether the system remains stable, adapting and learning but not transforming, or whether it is pushed close to a threshold that tips the system into a new stability domain. The new domain may share characteristics with the old stability domain but will have radically different feedback loops, and hence different relationships between the phases (Moore and Westley, 2011). Resilience theory offers a systems-level model of the emergence and dissemination of patterns of social innovation.

That social innovation occurs in multiple contexts of praxis serves to reinforce the need for theoretical particularity in the analysis and presentation of the phenomenon (Moulaert et al., 2014a). Thus, each case of social innovation in healthcare, education, economic development, agriculture, urban development or governance and political transformation will need its own epistemology and set of boundaries and logics if it is to be understood clearly. This is, of course, a methodological, as well as theoretical, challenge for researchers.

\section{Objectives of this book}

This collection aims to contribute to the small but growing research literature on social innovation. In particular, it attempts to challenge some of the emerging normative assumptions concerning the 'promise' of social innovation via critical analyses, extending and testing relevant theory, and via new empirical contributions. One important contribution of this volume is to test the assumption that social innovation is somehow inherently 'good' or socially positive in all contexts. As noted above, it is easy to imagine a 'dark side' to social innovation (as highlighted here by McGowan and Westley). However, even self-evidently positive social 
innovation may not benefit all relevant stakeholders equally and may, indeed, create negative effects for some. Moreover, the disruptive effects of some social innovation may undermine important institutional norms whilst still delivering substantial benefits to target populations. For example, some analyses of the role of social innovation in welfare services delivery would emphasise that this simultaneously undermines the roles and responsibilities of the state (and, therefore, citizens' democratic rights) as it delivers measurably positive benefits to target populations (see Evers and Ewert here). Unger also notes the need for social innovation to 'aim high' by acknowledging - and confronting - political and power issues across societies. The danger, otherwise, is that social innovation becomes absorbed into existing systems - tamed into irrelevance.

This collection also intends to help build a global community of researchers in social innovation by bringing together a range of perspectives and examples from around the world. The authors included here range across a variety of disciplines - management, political science, not-for-profit studies, sociology and economics - making this volume an avowedly multi-disciplinary endeavour. This is not only intellectually interesting but also reflects the reality of praxis in social innovation that is often characterised by cross-sector collaboration and organisational hybridity.

This book offers examples and insights from multiple geographical contexts and reflects many different cognitive frames, discourses and debates concerning the nature and enactment of social innovation. The innovation within this book itself lies in its presentation of new cases, new theories and new methodologies allied to different levels and units of analysis across its chapters.

Finally, this collection hopes to contribute meaningfully to emergent policy debates across countries concerning the role and functioning of social innovation across the commercial, not-for-profit and public sectors (and in the blurred institutional spaces between them). The contributions here serve to codify and analyse practice in a way that can inform better public policy decision-making. Academic research can play a significant role in this regard since it often explores models and issues that sit ahead of current policy debates and agendas. It is the ambition of this collection to offer such insights.

\section{Key themes}

The various contributions in this collection have a number of common themes and topics. 
First, this volume offers a number of new observations concerning the practice and process of researching social innovation. A foundational question asked here is: Is there a need for specific theories of social innovation or is social innovation simply a phenomenon that can be observed and made sense of using existing theoretical frameworks? Moreover, if the latter is true, then which disciplines best suit this analytic purpose? Partly to answer this, the chapters in this volume offer a rich and broad range of theoretical approaches to framing and analysing social innovation. They also touch on several important methodological issues. There are three chapters that present detailed case material from different countries (Brazil, South Korea and India): each offers new and rich empirical evidence of social innovation in context.

Second, and perhaps unsurprisingly, there is a clear focus on exploring the nature of social innovation. Overall, the research presented here situates social innovation as a 'quasi-concept' characterised by its fluidity in terms of its meanings and attendant discourses. This, of course, is a contingent effect of the widely observed tendency of social innovation to occupy hybrid institutional spaces and organisational forms. Specifically, the approaches to the nature of social innovation set out here include discussions of definitions with particular emphasis on the implications of social innovation at different socio-structural levels and at different stages of the innovation lifecycle from emergence to institutionalisation and, ultimately, entropy and re-invigoration as a new cycle begins (within the resilience model). The analysis of lifecycle issues also focuses on process questions around the dissemination, diffusion, growth and scaling of social innovation in various contexts.

Several chapters explore the nature of social innovation in terms of the complex interactions between individual actors and the systems in which they are located - this work reflects the central sociological debates concerning the roles of agency and structure in determining the shape and functioning of social action. This book also highlights examples of cross- or multi-sector collaboration (often in network settings) as defining features of successful social innovation. Research here demonstrates how successful examples of cross-sector partnerships also need to be carefully calibrated to their socio-cultural contexts.

A final focus of this collection is on the effects of social innovation. Within this topic there is a strong interest in democratic and public sector reform. This is manifest in social innovation aimed at citizen engagement and improved political accountability and transparency, on the one hand, and examples of innovative public service reform, on the other. The former is also analysed in terms of practical examples 
of innovations in governance and accountability mechanisms and models. Connected to these themes is research here that explores social innovation directed towards disrupting the (unjust) status quo of power structures via an explicit social change agenda. This theme also acknowledges the significance of community-level innovation and action. Another research focus examines how social innovation shapes, is shaped by and interacts with market structures and models. This set of work lies in stark contrast to the public sector focus noted elsewhere and provides a useful counterpoint to it, enriching the overall scope and argument of the book as a whole.

\section{Structure of the book}

The collection opens with some reflections by Mulgan on the future of social innovation research. He argues that social innovation rests on an idea about possibility, rather than being a field with clearly defined boundaries. As such, social innovation research cannot be simply a detached, empirical social science; it is inevitable - and healthy - that research is coupled with practice.

After this introduction, the book is divided into three parts: researching social innovation; blurring boundaries and reconfiguring relations; and producing social innovation through new forms of collaboration.

Part I examines a range of issues concerning the research of social innovation. This section explores new methodological approaches that can help to understand the roles of particular social innovation actors and to identify broader patterns and trends regarding the relationship between social innovation, social change and societal transformation.

The theoretical foundations of the concept of social innovation remain relatively weak and much research in this area is descriptive or evaluative. To further develop the theory underpinning social innovation research, one potential approach is to revisit the works of social theorists whose frameworks and models can help to make sense of critical issues within social innovation discourses. In Chapter 1, Howaldt, Kopp and Schwarz revisit the work of Gabriel Tarde and make a case for using his social theory in developing a theoretically grounded concept of social innovation. Tarde's basic idea is to explain social change 'from the bottom up'. Countless and nameless inventions and discoveries change society and its practices through equally countless acts of imitation, and only as a result do they become a true social phenomenon. By identifying the practices and laws of imitation as central to social innovation and social change, the authors propose shifts of perspective 
relevant to contemporary social innovation policy and discussions about the diffusion of social innovations.

Another approach to researching social innovation, exemplified in Chapter 2, is the use of comparative historical case studies. McGowan and Westley introduce a theoretical and methodological framework based on three propositions: first, that new social phenomena create the opportunity for changes to social relations and structures by enabling glimpses into the 'adjacent possible'; second, that agents' behaviour and roles within social innovation can be divided into three categories poets, debaters and designers - whose efforts are complementary; and finally, that to achieve broad, lasting change, the innovation in question must cross multiple scales - from the niche (micro) level to the (macro) landscape level. The authors explore these frameworks through a case study on the emergence of the intelligence test. This illustrates the three elements within the authors' theoretical framework and also shows how social innovation is culturally contingent. The ideas that inspired the development of the intelligence test, such as Social Darwinism, are now widely viewed as profoundly perverse.

In 2011, the Centre de recherche sur les innovations sociales (Center for Research on Social Innovations - CRISES) started to build a database of social innovations. In Chapter 3, Bouchard et al. examine the uses and the challenges of building such a database. Since research on social innovation is generally conducted through case studies, it is difficult to carry out macro-sociological analysis of the social transformations that accompany these innovations, and results cannot be generalised. The database of social innovations aims to fill this gap and to enable the longitudinal, sectoral and spatial analysis of social innovation in the context of Quebec. The process of building a database represents an innovative approach to the research of social innovation, and the authors point to a number of methodological, theoretical and epistemological challenges associated with such a task.

Part II explores some of the ways in which social innovations reconfigure relations between civil society, the state and the market. Indeed, the boundaries between these sectors are becoming increasingly porous and one of the striking features of social innovations is their ability to combine the traditionally disparate logics of the private, public and civil society sectors.

In Chapter 4, Jenson examines some of the varied meanings of the 'quasi-concept' of social innovation, and argues that one of its major contributions is to provide a novel way to reorganise market relations in the post-neoliberal world. The 'welfare diamond' is a heuristic device 
that illustrates the mixed sources of well-being, which include the market, the state, the family and the community. Each is a potential source of well-being. Increasing reliance on social entrepreneurs and social enterprises to achieve social innovations in social policy implies a reconceptualisation of relations within the welfare diamond, often by explicitly exposing and developing a reliance on non-market dimensions (such as community engagement and public policy) in the processes of market making and in quasi-markets.

Chapter 5, by Evers and Ewert, looks at the welfare diamond from a different perspective. The chapter describes and analyses approaches and instruments used in a range of innovative welfare projects from twenty cities and ten countries across Europe. Analysing these reveals recurring approaches and instruments in relation to various dimensions of welfare systems. The chapter reflects on the relationship between social innovation in the welfare field and welfare reform, and raises challenges for both. The economic precariousness caused by flexible labour markets, together with growing levels of in-work poverty, high levels of unemployment and squeezes to welfare entitlements and pensions, probably creates more significant social problems than could ever be addressed through socially innovative services that empower citizens and communities. This raises questions about the ability of social innovation to live up to its 'promise', and shows that, in order for social innovations to have real impact, engaging with political processes is essential.

Chapter 6 provides empirical evidence of the ways in which social innovations reconfigure market relations and blur boundaries between sectors, in this case between the market and civil society. Cipolla, Melo and Manzini describe the development and emergence of a new type of 'collaborative service' in a pacified favela in Rio de Janeiro. The pacification process enabled a local energy company to start offering services in the favela, but residents found it difficult to pay their bills. To overcome these challenges, the energy company developed 'Light Recicla', a service that reduced residents' electricity bills by exchanging recyclable materials for energy credits. Based on this case study, the authors discuss the possibility of building a new type of service based on vertical, experiential interactions between service providers and service users in informal settlements such as favelas.

While Part II explores issues about structure in generating social innovation, Part III examines some of the key issues around agency. In particular, it looks at the roles played by social innovation actors - such as social entrepreneurs, citizens and public sector managers - and explores 
how these roles can be strengthened in order to support the generation of social innovation. The chapters in this section underline the importance of collaboration in producing social innovation, even while some also highlight the roles of key individuals in the process, such as Mayor Park in Seoul. In this way, the chapters in this section echo arguments made by Howaldt et al. and McGowan and Westley, which emphasise the roles of different actors within the social innovation process.

In Chapter 7, Sørensen and Torfing argue that multi-actor collaboration in networks, partnerships and inter-organisational teams can spur public innovation. They argue that the principles of New Public Management are giving way to 'New Public Governance', and that the enhancement of collaborative innovation has now become a key aspiration of many public organisations around the world. However, collaborative and innovative processes are difficult to trigger and sustain without proper innovation management and a supportive cultural and institutional environment. Arguing strongly that innovation is produced through collaboration and not through the actions of 'heroic individuals', the authors describe the roles for public innovation managers that are necessary to enhance innovation through collaboration.

In Chapter 8, Han, Kim, Rim and Park provide an empirical case study from Seoul. Led by Mayor Park, a famous social innovator, Seoul Metropolitan Government has developed various communication channels, both online and offline, which have enabled new forms of consultation and engagement between the city administration and citizens. The chapter outlines three communication tools and programmes that reflect the current administration's approach and values, and presents a case study of a particular challenge that the city government solved through engaging with citizens. New communication tools often have a limited reach, and the methods currently being used only contribute to solving a limited range of social problems. Nevertheless, Seoul Metropolitan Government's approach offers valuable lessons to other cities that are ambitiously planning to initiate and drive social innovation.

In Chapter 9, Tjornbo examines whether the wisdom of crowds can be harnessed to generate social innovation. The development of modern information and communication technologies has led to a renewed interest in the phenomenon of collective intelligence, defined here as the capacity to mobilise and coordinate the knowledge, skills and creativity possessed by large groups of individuals, and combine them into a greater whole. Social innovation is deeply reliant on the capacity to combine the ideas, knowledge and resources possessed by disparate 
groups, something collective intelligence can do well. However, it is also clear that collective intelligence has serious limitations when it comes to dealing with complex problems that are politically contested and require careful coordination. This chapter provides a framework for examining how collective intelligence might support social innovation and explores three existing collective intelligence platforms that have promoted social innovation: Innocentive, Open Source Ecology and TED.

Chapter 10 examines how successful social entrepreneurs use networks to build their businesses. Focusing on social entrepreneurs as a particular sub-group of social innovators, Sonne maps the individual networks of three innovative social enterprises in India. Analysing these networks helps to improve understanding of to whom social entrepreneurs turn for access to knowledge and financial and non-financial support in order to innovate, build and grow their businesses and develop social capital. The author also explores the way in which social entrepreneurs build the relationships that form the basis of their networks and the ways in which important networks change over time.

In the book's conclusion, Roberto Mangabeira Unger offers a manifesto for the social innovation movement: he explores the impulses driving the movement and argues for a view of what its agenda and methods can and should be. In this 'maximalist' view, the task of the social innovation movement is to challenge the worldwide 'dictatorship of no alternatives' by addressing 'the whole of society, of its institutional arrangements, and of its dominant forms of consciousness'. The best way to carry out this task is to take small-scale experimental initiatives that both mark a path for society and represent first steps for treading it. For Unger, the overriding mission of the social innovation movement is the enhancement of agency - our power, as individuals and as collectivities, to reshape our world. It is to help create a society of innovators.

\section{Conclusions}

This chapter has set the context for the remainder of the volume and has summarised the key contributions of the research featured here. However, there are several important and interesting topics of relevance to social innovation that would benefit from future research. Six such topics are sketched out below.

An important feature of social innovation that has sometimes been overlooked in the literature to date is political disruption. The social movements literature suggests that truly systemic change only comes 
about through struggle and changing the dominant cognitive frames that frame social issues. Such activity typically comes up against strong vested interests and can encounter (sometimes violent) resistance. As a consequence, the politicisation of social innovation research offers an important new lens through which systemic change can be understood: recognising the political dimension of social innovation is not merely a research opportunity, but it also raises significant practical questions and challenges. Political action often prompts a reaction and can lead to institutional confrontation or even danger. Further, when social innovation addresses public welfare issues or aims to drive political change, it typically does so as private action that lacks any formal democratic legitimacy. This is particularly problematic in cases where social innovation acts as a 'shadow state' substituting for what would otherwise be the welfare responsibilities of the elected state. Such a democratic deficit challenges rights-based models of citizens' relationship to their government. There is also the more general issue of who is included in, and who is excluded from, social innovation impacts.

A second issue concerns the public legitimacy of social innovation. Many social innovations that aim to address institutional voids may initially lack legitimacy to key populations. This is because they often take the form of interventions that combine otherwise distinct institutional logics and models of action in innovative forms and that challenge normative notions of the roles and responsibilities of the discrete sectors. Such hybrid forms of action typically blend the logics and rationales of two or more established sectors to build new organisational structures (i.e., 'social' business), processes (i.e., work integration models) or goods and services (i.e., user-led welfare models) that correspond to complex sets of needs and demands in late modern societies better than conventional interventions do. The logics and rationales of action of each conventional sector are quite different and even contradictory at the normative level. As a consequence, the public legitimacy of social innovation (at both normative and cognitive levels: see Suchman, 1995) can often be compromised, with new models variously seen as attempts to privatise the social, dismantle the state or undermine civil society (Nicholls and Cho, 2006). The reaction to the social enterprise/social business hybrid model within social innovation has been particularly hostile since this challenges fundamental principles of the state and civil society as not-for-profit sectors in many countries. Such loss of public legitimacy can have serious consequences in terms of access to resources, market competitiveness, policy support and staff recruitment. 
Third, there are challenges in scaling up social innovation. The stated objective of much social innovation is to bring about systemic change. However, genuine systems change is a very ambitious objective and typically requires a combination of scale, geographical spread and political support. Bloom and Chatterji (2009) acknowledged these factors when they established the SCALERS model as a guide to key activities needed to achieve scale in social innovation, notably in terms of staffing, communicating, alliance building, lobbying, earnings generation, replicating and stimulating market forces. Elsewhere research has focused on the institutional, rather than organisational, aspects of achieving scale, particularly in terms of building social innovation 'ecosystems' (Bloom and Dees, 2008). However, there is relatively little evidence as yet of social innovation delivering systems change without government support - which begs important questions about the public-private dimensions of scaling social innovation.

Fourth, social innovation is often limited by access to market - or even discretionary - commercial finance at the start-up and growth phase (Nicholls, 2010b). There are several reasons for this. First, as was noted above, social innovation often occupies hybrid institutional spaces that span the logics of the state and the for-profit and not-for-profit sectors. This creates difficulties in terms of assessing risk and return within conventional financial modelling. Furthermore, given its explicit social focus, social innovation 'ventures' may not aim at maximising their financial bottom line, focusing instead on creating 'blended value' (Emerson, 2003) that combines social and financial performance. A third challenge is investor exit - there is currently no fully functioning secondary market in which social innovation investments can be realised. The emergence of an impact investing market (O'Donohoe et al., 2010) over recent years may partly address this capital gap - but it seems likely that, going forward, public and philanthropic finance will remain important to develop and grow social innovation.

Fifth, there are, as yet, no agreed measurement mechanisms or standard units of analysis for social innovation impact and performance. Welfare economics and the large range of bespoke social impact measurement approaches developed within the not-for-profit or social entrepreneurship sectors offer a set of models that can be used in different contexts, but no dominant standard has emerged (Mulgan, 2010; Ebrahim and Rangan, 2010). As a consequence, exploring the comparative performance of social innovation remains a challenge. This has profound implications for access to capital and policy making. 
Related to the problems of measuring social innovation impact is a sixth challenge. As has already been suggested, social innovation may have problematic unintended or accidental consequences or externalities. There are four issues to be considered here. First, social innovation can have negative social effects by excluding some groups from the focus of its provision of social goods and services or its campaigns for social change. Second, another unintended set of consequences can arise from different framings or perceptions of the hybrid nature of social innovations that blend social and financial objectives. From one point of view such activities are exploitative and represent the 'privatisation' of the social, as critiques of the high interest rates offered by many micro-finance organisations have pointed out. Third, social innovation could be hijacked for socially divisive or destructive objectives and intentions, for example by secret societies or extreme political parties. Finally, social innovation can achieve perverse effects in cases of operational failure (e.g., Tracey and Jarvis, 2006). Since social innovation is often expressed organisationally in the form of innovative start-ups in weak institutional spaces, it is inherently risky. As a result, it is reasonable to expect that much social innovation will fail, with potentially damaging effects for vulnerable populations.

Finally, it is important to note that social innovation is often highly contingent and contextually sensitive. It will therefore look quite different in different countries. Thus, outside of the United States and Europe, social innovation has very different political-economic contexts (see Kerlin, 2009). For example, in the transition countries of Eastern Europe after the fall of communism, weak market structures, significant injections of international aid and a rejection of centralised organisational forms led to the development of social innovation focused on creating small businesses that rejected the co-operative and mutual form due to cultural-political reasons of history. In Latin America, after the financial crisis of the late 1990s, market, state and international aid structures were severely weakened. In this context, social innovation evolved, first, as a mechanism of social solidarity built from the grass roots up (Klein, 2002) and, then, as mechanisms to rebuild jobs and regenerate economies (see, e.g., NESsT, 2005). In Africa, social innovation emerged at the intersection of state and market failures (sometimes bordering on actual collapse) and was often driven by high levels of extreme poverty and large inflows of international development aid. Particularly significant here was the provision of microcredit for small businesses, as well as the emergence of innovative organisations in health, education and farming. More recently, there has been a strong focus on environmentally sustainable businesses and enterprises, particularly in green technology, often funded by international investors. 
Finally, in parts of South and South East Asia - notably Bangladesh and India - social innovation has emerged to address a combination of minimalist state welfare structures and growing welfare failures. This did not reflect state failure or welfare crises on an African scale, but rather was the product of a context in which the relationship between the private individual and the state was often remote and problematic. In the case of the Grameen Bank and BRAC in Bangladesh, for example, social innovation reached a national scale, with these two organisations functioning as a shadow state delivering financial services, employment, health and education to many more citizens than the elected state.

Social innovation offers an exciting space for research and debate, but it also offers the potential to bring about substantive changes in the alignment of resources, policy and societal structures to address the major issues of modernity across many different countries. This is very much a dynamic project - a constantly renewing work-in-progress that has an inbuilt self-reflexivity and self-critique - working across many sectors (and their interfaces) and at many socio-structural levels. The empirical project to test and map the impact and effectiveness of social innovation is only at an early stage of development, but a better understanding of the trends, blueprints, challenges and opportunities is emerging. It is to this vibrant and international conversation that this book hopes to contribute.

\section{Notes}

1. There are two additional issues here. First, there is a growing disconnect between traditional services and new needs - health services, for example, were originally designed to deal with acute rather than chronic disease, but it is chronic disease which is becoming more prevalent across many societies. Second, it has proved difficult to offset growing demands on services through cost savings and efficiencies.

2. Broadly known as New Public Management (Hood, 1991), this new paradigm in public administration was based on the idea that if applied to the public sector, private sector management tools and techniques and the creation of quasi markets or internal markets to enable choice and competition could drive innovation and efficiency savings and increase user satisfaction.

3. Some of these themes have been further developed more recently by the Design for Social Innovation and Sustainability (DESIS) Network: http://www. desis-network.org [Accessed 26 November 2014].

\section{References}

Alter, K. (2006) 'Social Enterprise Models and Their Mission and Money Relationships', in A. Nicholls (ed.), Social Entrepreneurship. New Models of Sustainable Social Change. Oxford: Oxford University Press, pp. 205-32. 
Bartlett, J. (2009a) At Your Service: Navigating the Future Market in Health and Social Care. London: Demos.

Bartlett, J. (2009b) Getting More for Less: Efficiency in the Public Sector. London: Demos.

Battilana, J. and Dorado, S. (2010) 'Building Sustainable Hybrid Organizations: The Case of Commercial Microfinance Organizations', Academy of Management Journal, 53 (6): 1419-40.

Bloom, P. and Chatterji, A. (2009) 'Scaling Social Entrepreneurial Impact', California Management Review, 51: 114-33.

Bloom, P. and Dees, J.G. (2008) 'Cultivate Your Ecosystem', Stanford Social Innovation Review, 6: 46-53.

Bovaird, T. (2006) 'Developing New Forms of Partnership with the "Market" in Procurement of Public Services', Public Administration, 84 (1): 81-102.

Davis, G., McAdam, D., Scott W.R. and Zald, M. (eds) (2005) Social Movements and Organization Theory. Cambridge: Cambridge University Press.

Dees, J.G. (1998) The Meaning of Social Entrepreneurship, available at: http://www. caseatduke.org/documents/dees_sedef.pdf [Accessed 26 November 2014.]

Drayton, W. (2002) 'The Citizen Sector: Becoming As Entrepreneurial and Competitive As Business', California Management Review, 44 (3): 120-32.

Ebrahim, A. and Rangan, K.V. (2010) 'The Limits of Nonprofit Impact: A Contingency Framework for Measuring Social Performance', Harvard Business School General Management Unit Working Paper, 10-99.

Emerson, J. (2003) 'The Blended Value Proposition: Integrating Social and Financial Results', California Management Review, 45 (4): 35-51.

Fairweather, G. (1967) Methods for Experimental Social Innovation. Hoboken, NJ: John Wiley.

Hämäläinen, T. and Heiskala, R. (eds) (2007) Social Innovations, Institutional Change and Economic Performance: Making Sense of Structural Adjustment Processes in Industrial Sectors, Regions and Societies. Cheltenham, UK: SITRA and Edward Elgar.

Henderson, H. (1993) 'Social Innovation and Citizen Movements', Futures, April: 322-38.

Holt, K. (1971) 'Social Innovations in Organizations', International Studies of Management and Organization, 1 (3): 235-52.

Hood, C. (1991) 'A Public Management for All Seasons?', Public Administration, 69 (1): 3-19.

Kerlin, J. (ed.) (2009) Social Enterprise: A Global Comparison. Medford, MA: Tufts University Press.

Klein, N. (2002) Fences and Windows. London: Flamingo.

Leadbeater, C. (1997) The Rise of the Social Entrepreneur. London: Demos.

Mair, J. and Marti, I. (2009) 'Entrepreneurship In and Around Institutional Voids: A Case Study from Bangladesh', Journal of Business Venturing, 24 (5): 419-35.

Moore, M. and Westley, F. (2011) 'Surmountable Chasms: Networks and Social Innovation for Resilient Systems', Ecology and Society, 16 (1): 1-5.

Moss Kanter, R. (1999) 'From Spare Change to Real Change: The Social Sector as Beta Site for Business Innovation', Harvard Business Review, May-June: 122-32.

Moulaert, F., Martinelli, F., Gonzalez, S. and Swyngedouw, E. (2007) 'Introduction: Social Innovation and Governance in European Cities', European Urban and Regional Studies, 14 (3): 195-209. 
Moulaert, F., MacCallum, D., Mehmood, A. and Hamdouch, A. (eds) (2014a) The International Handbook on Social Innovation: Collective Action, Social Learning and Transdisciplinary Research. Cheltenham: Edward Elgar.

Moulaert, F., MacCallum, D., Mehmood, A. and Hamdouch, A. (2014b) 'General Introduction: The Return of Social Innovation as a Scientific Concept and a Social Practice', in Moulaert, F.,Mulgan, G. (2010) 'Measuring Social Value', Stanford Social Innovation Review, Summer: 38-43.

Mulgan, G., Tucker, S., Ali, R. and Sanders, B. (2007) Social Innovation: What it is, why it matters and how it can be accelerated. Oxford: Skoll Centre for Social Entrepreneurship.

Mumford, M. (2002) 'Social Innovation: Ten Cases from Benjamin Franklin', Creativity Research Journal, 14 (2): 253-56.

Murray, R., Caulier-Grice, J. and Mulgan, G. (2010) The Open Book of Social Innovation. London: Young Foundation.

NESsT (2005) Risky Business: The Impacts of Merging Mission and Business. Santiago: NESsT Learning Series.

Nicholls, A. (ed.) (2006) Social Entrepreneurship: New Models of Sustainable Social Change. Oxford: Oxford University Press.

Nicholls, A. (2010a) 'The Legitimacy of Social Entrepreneurship: Reflexive Isomorphism in a Pre-Paradigmatic Field', Entrepreneurship Theory and Practice, 34 (4): 611-33.

Nicholls, A. (2010b) 'The Institutionalization of Social Investment: The Interplay of Investment Logics and Investor Rationalities', Journal of Social Entrepreneurship, 1 (1): 70-100.

Nicholls, A. (2013) 'The Social Entrepreneurship-Social Policy Nexus in Developing Countries', in Walker, D. and Surrender, R. (eds), Social Policy in a Developing World: A Comparative Analysis. Oxford: Oxford University Press, pp. 183-216.

Nicholls, A. and Cho, A. (2006) 'Social Entrepreneurship: The Structuration of a Field', in Nicholls, A. (ed.), Social Entrepreneurship: New Models of Sustainable Social Change. Oxford: Oxford University Press, pp. 99-118.

Nicholls, A. and Murdock, A. (eds) (2012) Social Innovation: Blurring Boundaries to Reconfigure Markets. Basingstoke: Palgrave Macmillan.

Nicholls, A. and Opal, C. (2005) Fair Trade: Market-Driven Ethical Consumption. London: Sage.

Nyssens, M. (2006) Social Enterprise. Basingstoke: Palgrave Macmillan

OECD (2011) LEED Forum on Social Innovations.

Offer, A. (2006) The Challenge of Affluence. Oxford: Oxford University Press.

O'Donohoe, N., Leijonhufvud, C. and Saltuk, Y. (2010) Impact Investments: An Emerging Asset Class. New York: JP Morgan Global Research and the Rockefeller Foundation.

Phills, J., Deiglmeier, K. and Miller, D. (2008) 'Rediscovering Social Innovation', Stanford Social Innovation Review, Fall: 34-43.

Osborne, D. and Gaebler, T. (1992) Reinventing Government: How the Entrepreneurial Spirit Is Transforming the Public Sector. Reading, MA: Addison-Wesley.

Pot, F. and Vaas, F. (2008) 'Social Innovation, the New Challenge for Europe', International Journal of Productivity and Performance Management, 57 (6): 468-73.

Porter, M. and Kramer, M. (2011) 'Creating Shared Value', Harvard Business Review, January-February, 89 (1/2): 62-77. 
Prahalad, C.K. (2006) The Fortune at the Bottom of the Pyramid. Upper Saddle River, NJ: Pearson.

Rayner, S. (2006) Wicked Problems: Clumsy Solutions - Diagnoses and Prescriptions for Environmental Ills. Jack Beale Memorial Lecture on Global Environment.

Rittel, H. and Webber, M. (1973) 'Dilemmas in a General Theory of Planning', Policy Sciences, 4: 155-69.

Schumpeter, J.A. (1942) Capitalism, Socialism and Democracy. New York: Harper and Row.

Suchman, M. (1995) 'Managing Legitimacy: Strategic and Institutional Approaches', Academy of Management Review, 20 (3): 571-610.

Tracey, P. and Jarvis, C. (2006) 'An Enterprising Failure: Why a Promising Social Franchise Collapsed', Stanford Social Innovation Review, Spring: 66-70.

Westley, F. and Antadze, N. (2010) 'Making a Difference: Strategies for Scaling Social Innovation for Greater Impact', The Innovation Journal: The Public Sector Innovation Journal, 15 (2): 1-19.

Zeschky, M., Widenmayer, B. and Gassmann, O. (2011) 'Frugal Innovation in Emerging Markets', Research-Technology Management, 54 (4): 38-45.

Except where otherwise noted, this work is licensed under a Creative Commons Attribution 3.0 Unported License. To view a copy of this license, visit http://creativecommons.org/licenses/by/3.0/ 